\title{
Factors affecting the competition of an irrigation construction project using state budget funds
}

\author{
Trong Lam Vu $u^{a}$, Ngoc Toan Nguyen ${ }^{b^{*}}$ and Thi To Phuong Nguyen
}

${ }^{a}$ Communist Review, Vietnam

${ }^{b}$ University of Economics - Technology for Industries, 456 Minh Khai, Hai Ba Trung, Ha Noi, Vietnam

\section{H R O N I C L E}

Article history:

Received: May 1, 2021

Received in revised format: May

6, 2021

Accepted: June 3, 2021

Available online:

June 10, 2021

Keywords:

Progress of completing

Irrigation construction project

Vietnam

\section{A B S T R A C T}

\begin{abstract}
The objective of this paper is to evaluate factors affecting the progress of completing construction of irrigation projects using state budget funds. To achieve the goal, to research and conduct surveys of investors, contractors, managers of irrigation construction investment projects. Analysis results from 269 valid questionnaires using SmartPLS 3.6 software showed that all 6 factors: Investor, Peripheral, Capital, Contractors, Consultant, Convenience, all factors have a positive impact on progress of completing irrigation construction projects using state budget funds in Thai Binh province, Vietnam.
\end{abstract}

(C) 2021 Growing Science Ltd. All rights reserved.

\section{Introduction}

To effectively manage investment capital from the State budget, project completion progress is a key factor determining effective capital management. Because the capital management process depends on the project completion process. Therefore, in this section, the authors study in-depth the factors affecting the progress of completing the construction of irrigation works using the State budget in Thai Binh. Completing an irrigation project on schedule is one of the top factors in evaluating a successful project, and effectively managing investment capital. Getting a project to work on schedule is a complex process that involves planning, monitoring, and controlling all aspects of a project; stimulating all actors to participate in that project to achieve the project objectives on time with costs, quality, and capabilities available. However, the construction industry is one of the specific industries, so during the construction process, there are always many difficulties, such as administrative procedures, contractor (construction party) capacity, and private investors. Some of the requirements in the construction process from the investor, especially the construction of irrigation works, depend heavily on natural conditions. Therefore, the construction industry is also influenced by many objective and subjective factors such as environment, weather, labor, equipment, materials, etc. In Thai Binh, most of the irrigation projects using State budget capital have been put into use yet do not meet the requirements of time, cost, and work quality, leading to construction projects. Irrigation works funded by the State budget have not completed progress as expected by the parties involved (slow completion of progress). The reason is that the investor is slow to hand over the site, the adjustment of construction design documents cost estimates, supervision consultancy is not tight, not guaranteeing the payment capital, disbursement of capital is not timely, arising from adjusting the price of materials, the main contractor does not guarantee construction capacity, etc. Specifically, the Southern Coastal Corridor; Cong Vu Thu belongs to the irrigation system project of Subregion X - Vu Thu; Total investment capital disbursement is 1,886 billion Dong, equal to $66 \%$ of the capital plan. In addition, there are projects that have not yet completed progress at the Provincial Construction Project Management Unit (total of 148 bidding packages). Therefore, in the Report on the implementation of the Resolution of the Provincial People's Council on the socio-

* Corresponding author.

E-mail address: nntoan@uneti.edu.vn (N. T. Nguyen)

(C) 2021 Growing Science Ltd. All rights reserved. doi: $10.5267 /$ j.jpm.2021.6.001 
economic development task of Thai Binh province (2017 - 2018) has identified several key tasks of house management. water in the fields of planning - architecture, urban development and technical infrastructure, housing development, the management and maintenance of rural transport infrastructure are regularly coordinated by the relevant authorities. subsidence has been overcome and the work of maintaining and repairing damaged and degraded roads has met the needs of people to circulate and transport goods. The slow completion of the construction projects of irrigation works using state budget funds in Thai Binh province has caused some negative impacts on individuals and society at present. Typically, it is wasting human and material resources, reducing the efficiency of capital use, failing to achieve the goal of creating a favorable business environment, stabilizing the socio-economy, improving income, increasing high quality of life of the people, and creating a competitive advantage for the locality. There are many factors leading to the delay in the project, the extent of the project being incomplete compared to the original plan. From there, reducing efficiency when putting the project into operation or even causing the project to fail. Therefore, it is very important to identify the factors that influence the project completion progress from start to finish. Currently, in Thai Binh, there are no studies to evaluate the factors affecting the progress of completing construction of irrigation works to help the project participants identify the causes of progress. the completion of the irrigation work construction project.

Construction investment projects of the public sector always account for a high proportion in the construction industry, the success or failure of this type of project will greatly affect the society in many aspects. Construction projects in the public sector always come with a relatively complex procedure, going through many stages from investment preparation to completion, handover, and use. to many State agencies such as construction management agencies, financial management agencies, banks, treasury, etc. Therefore, research to evaluate the factors affecting the completion progress and solutions to increase the likelihood of success for construction projects in the public sector is very necessary.

This paper presents the results of a study aimed at identifying and analyzing the factors affecting the progress of completion of an irrigation project using budget funds and proposing mitigation measures. the harm of the risks.

The structure of the article in addition to the introduction includes: Research overview, research methods, research results and conclusions.

\section{Literature review}

Irrigation work construction projects are projects to build works using State budget capital or using State budget capital with a minimum percentage as prescribed by law. Nguyen et al. (2004) identified five factors most influencing the success of large projects (valued at over USD 1 million) in Vietnam: Project Commitment; Adequate funding throughout the project; Sufficient resources; Project manager qualifications; Diversity / qualifications of the project management board. After factor analysis, the author identified 15 factors affecting success and grouped them into 4 groups called 4 COMs, including: comfort; competence; commitment; information (communication). The relationship between success factor (success factor) and PSI index (Project Success Index) was also determined by Hoang (2008). The PSI index according to this study is understood to include four factors: Project completion time; Project implementation costs; Project quality; Safety issues during implementation. For projects implemented according to the design - construction method, Ong et al. (2011) has also studied and drawn the most important success factors for this type of project are: Sufficient finance to complete the project; The commander in chief is capable, experienced, and powerful; The contractor is experienced and has high reputation; Contractors combine well between design plan and appropriate construction methods; Contractor has strong competence in design and construction management. The main factors affecting the success of the project are Chan et al. (2004) review includes: Project management activities; Project procedures; External environment; Factors related to the project; Factors related to people. For public construction projects, according to Tabish et al. (2011) as a whole, public construction projects are largely influenced by groups of factors: Perception and compliance with rules and regulations; Effective cooperation between the parties involved; Clearly plan and define the scope of the pre-project. Through an overview of the studies, this paper proposes the following factors:

\subsection{Consultant}

This group of factors represents the Competence of consultants in construction activities such as design consultancy, supervision consultant, project management consultant, cost management consultant. The higher the capacity of the Consultants, the less fluctuations in the completion progress of an irrigation construction project, which means that a project without construction may exceed or be completed on schedule and on time. Therefore, the author proposes a group of factors related to the consultant's capacity including:

- Personal capacity of Design Consultant.

- Personal capacity of Supervision Consultant.

- Personal capacity of project management consultant.

- Ability to exchange information between the Consultant and the Investor. 
- Capacity of coordination between the Consultant and the Contractor.

- Support capacity of Consultant and Investor.

Hypothesis $\mathrm{H}_{1}$ : The Consultant group has a negative correlation to the project progress. In other words, the higher capacity of the consultants, the shorter the project progress.

\subsection{Investor}

This group of factors represents the Investor's capacity. Investors need to have certain abilities such as providing project information in a timely manner to project stakeholders; being knowledgeable about construction law; coordinating implementation of the contract with the parties to the project; solving the difficulties and troubles of the project. The author expects that the Investor's capacity has a negative correlation with the project progress, or the higher the Investor's capacity, the shorter the project progress will be. Therefore, the author proposes a group of factors related to the Investor's capacity including:

- Competence to authorize subordinates.

- Negotiation capacity.

- Capacity to coordinate with the parties involved in the project.

- Ability to make decisions.

- The project's capacity to solve arising difficulties and problems.

- Awareness of the Investor's roles and responsibilities.

Hypothesis $\mathrm{H}_{2}$ : The Investor related factors group has a negative relationship to the project progress. i.e., the higher the capacity of the Investor, the shorter the project progress.

\subsection{Contractors}

This group of factors shows the Contractor's capacity, this capacity is reflected in a number of points such as the ability to manage project finance; Show full responsibility in the project construction process; closely coordinate with the parties involved in the project; has a team of professional staff, with a sense of responsibility, high technology; having modern and complete construction equipment and machinery ...; The author expects that the Contractor's capacity has a negative correlation with the project progress, or the higher the Investor's capacity, the shorter the project progress. Therefore, the author proposes a group of factors related to the Contractor's capacity including:

- Personnel capacity of Main Contractor,

- Main contractor's financial capacity,

- Machine and equipment capacity of the Main Contractor,

- Main contractor's financial management capacity,

- Capacity for coordination between Contractor and Investor,

- Ability to exchange information between the Contractor and the Consultant and the Investor.

Hypothesis $\mathrm{H}_{3}$ : The group of factors related to the contractor has a negative correlation to the project progress. In other words, the higher the capacity of the contractor, the shorter the project progress is.

\subsection{Capital}

This group of factors shows the willingness of capital to provide for the project such as timely provision of capital to the parties, effective financial resource management, and the author expects the availability of capital. for a project that is negatively correlated to the project's progress, or the higher the availability of funds to finance the project, the shorter the project progress will be. Therefore, the author proposes a group of factors related to Capital sources including:

- The project capital is fully and promptly provided for the participating parties,

- Effectively manage the State's financial resources,

- Balance and allocate capital in accordance with the approved plan,

- Settlement of capital payment in accordance with regulations and on time.

Hypothesis $\mathrm{H}_{4}$ : The group of factors related to capital in the project process has a negative correlation to the project progress. Or the more sufficient and timelier the capital in the project process is, the shorter the project progress will be shortened. 


\subsection{Peripheral}

This group of factors shows external factors that can affect changes in the completion of the project, this group of factors is related to objective and subjective factors such as natural conditions, economic factors, administrative procedures, legal policies, etc., the author expects external factors to have a negative correlation to the project progress, the higher the stability of these factors, the higher the expected progress. The sentence is shorter. Thus, the author proposes groups of factors related to peripheral factors, including:

- Finance is inflationary,

- Material prices increased out of control,

- Unforeseen geological and weather conditions,

- Errors and inconsistencies in the construction contract,

- Management agencies are slow to make decisions,

- Complicated legal procedures.

Hypothesis $\mathrm{H}_{5}$ : The group of factors related to the Peripheral factors has a negative relationship to the project progress. In other words, the higher level of stability of external factors, the shorter the project progress is.

\subsection{Convenience}

This group of factors represents different factors that can affect the completion of a project, this group of factors related to funding, contracts, human resources involved, legal procedures, ..., the author expects that the favorable factors in the project process are negatively correlated to the project progress, the higher the stability of these factors, the more the project progress is withdrawn. short. Therefore, the author proposes a group of factors related to Facilitation factors in the project process including:

- Adequate funding throughout the project,

- Full and comprehensive contract,

- Availability of resources,

- The continuous participation of the project participants,

- Clear, fast and timely payment procedures are instructed,

- High sense of responsibility of the parties involved in the project.

Hypothesis $\mathrm{H}_{6}$ : The group of factors related to the profitability in the project process has a negative correlation to the project progress, i.e., the more favorable factors are in the project process, the shorter the project progress.

\section{Research method}

Research sample is contractors, investors, management agencies for irrigation construction projects in Thai Binh province, Vietnam. To collect data, the author sent survey questionnaires to related parties such as contractors, investors, consultants, project management agencies, ... The author sent all 350 survey forms and concluded Results obtained 289 questionnaires, after classification and data entry into the software, only 269 valid votes were left for analysis. Based on theoretical research and inherited from the studies of different authors on the factors affecting the project progress. The author has exchanged, discussed, and consulted with several experts in the construction industry along with qualitative research. The author proposes a research model including the dependent variable and 06 independent variables. In which, the dependent variable is the change in the project completion progress; The independent variables are factors including (1) the consultant; (2) Investor; (3) Contractor; (4) Capital sources; (5) Peripheral and (6) Facilitation in the project implementation process. Accordingly, the dependent variable (changes in the project completion progress) and independent variables are identified:

TPI $=($ Actual $/$ Expected Time -1$) \times 100$

The possible scenarios are $T P I=\left\{\begin{array}{cc}>0 & \text { Project is behind schedule } \\ <0 & \text { Project exceeds progress } \\ =0 & \text { Project on schedule }\end{array}\right.$

On that basis, the multi-variable regression model was built by the author as follows:

$Y=\beta_{0}+\beta_{1} X_{1}+\beta_{2} X_{2}+\beta_{3} X_{3}+\ldots+\beta_{k} X_{k}+e_{i}$

where $Y$ : Dependent variable - Change in progress of completing a construction project. 
$\beta_{0}$ : Constant.

$\beta_{1}, \beta_{2}, \ldots, \beta_{\mathrm{k}}$ : Regression coefficients,

$\mathrm{X}_{1}$ : Consultant's group of factors,

$\mathrm{X}_{4}$ : Group of factors related to Capital Resources,
$\mathrm{X}_{2}$ : The group of factors related to the Investor,

$\mathrm{X}_{5}$ : Peripheral group of factors,
$\mathrm{X}_{3}$ : Group of factors related to Contractor,

$\mathrm{X}_{6}$ : Factors related to convenience.

The study uses qualitative research to determine the factors affecting the completion progress of investment projects in the construction of irrigation works using state budget funds. From there, proceed to build the scale. Then, consult experts in the construction and irrigation sector, the guidance of instructors and adjust the scale, add observed variables in groups of factors that influence the complete survey questionnaire. Quantitative research aims to measure the impact of factors affecting the completion progress of investment projects on construction of irrigation works using state budget funds, assessing the reliability of the scale. At the same time, test the research model. Use the 5-level Likert scale (from 1: totally disagree to 5: totally agree) to quantify. The author used SPSS 23 software and Smart PLS 3.6 software to analyze data and some analysis methods used in the topic such as: Descriptive statistical methods; Assessment of reliability coefficients Cronbach's Alpha; Exploratory Factor Analysis (EFA) (Henseler et al., 2009, 2015); calculate the average value of the scale to evaluate the influence of the independent factors on the dependent variable; Multivariate regression analysis method to test the suitability of the research model (Hair et al., 2011, 2014, 2017). From there, the author proposes the research model including the dependent variable and 06 independent variables. In which, the dependent variable is the change in the project completion progress; The independent variables are factors including (1) the consultant; (2) Investor; (3) Contractor; (4) Capital sources; (5) Peripheral and (6) Facilitation in project implementation process. Accordingly, the dependent variable (changes in the project completion progress) and independent variables are identified:

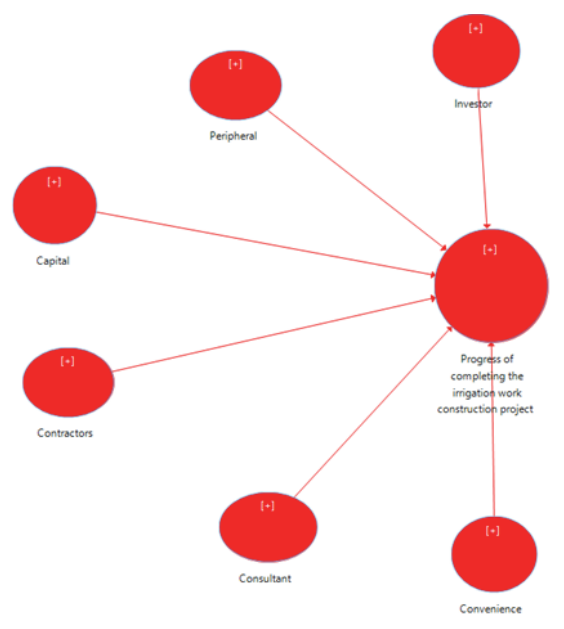

Fig. 1. Research model

Based on studies that have been done in the past, combined with factors that affect the success of the project. The author proposes 06 hypotheses with observed variables in 06 groups of factors affecting the progress of completing irrigation projects using State budget capital. The observed variables are also a prerequisite for establishing a questionnaire to identify factors influencing changes in the progress of completing the construction of irrigation works using State budget funds in Thai Binh province. The questionnaire will be sent to all stakeholders in several public investment projects in Thai Binh province. The author uses the 5-level Likert scale in the survey questionnaire, the Likert scale is the most used measure in socio-economic research and is evaluated according to 5 specific levels such as:

\begin{tabular}{lccccc}
\hline Level & 1 & 2 & 3 & 4 & 5 \\
\hline Effect & No effect & Little effect & Moderate effect & Much influence & Very much impact \\
\hline
\end{tabular}

\section{Result}

The study has built up 06 groups of factors affecting the progress of completing an irrigation project using State budget funds in Thai Binh province, including: (1) Consultant; (2) Investors; (3) Contractor; (4) Capital sources; (5) Peripheral; and (6) Convenience. Results of testing the scale with Cronbach's Alpha reliability coefficients and exploratory factor analysis (EFA). With 06 components and a scale of factors affecting the progress of completing an irrigation work construction project using State budget funds, Thai Binh province can reach the acceptable level of reliability. The results of testing the overall reliability of the scale are as follows: 
Table 1

Construct Reliability and Validity

\begin{tabular}{lcccc}
\hline & $\begin{array}{c}\text { Cronbach's } \\
\text { Alpha }\end{array}$ & rho_A & Composite Reliability & Average Variance Extracted (AVE) \\
\hline Investor & 0.911 & 0.911 & 0.911 & 0.672 \\
Peripheral & 0.890 & 0.890 & 0.890 & 0.669 \\
Capital & 0.898 & 0.898 & 0.898 & 0.638 \\
Contractors & 0.872 & 0.872 & 0.872 & 0.695 \\
Consultant & 0.910 & 0.911 & 0.910 & 0.629 \\
Convenience & 0.872 & 0.872 & 0.872 & 0.694 \\
\hline $\begin{array}{l}\text { Progress of completing the irrigation } \\
\text { work construction project }\end{array}$ & 0.982 & 0.982 & 0.982 & 0.666 \\
\hline
\end{tabular}

From the above table shows, all scales satisfy the reliability and validity conditions and qualified for the differential validity test.

Table 2

Discriminant Validity: The results of Fornell-Larcker Criterion

\begin{tabular}{|c|c|c|c|c|c|c|c|}
\hline & Investor & Peripheral & Capital & Contractors & Consultant & Convenience & $\begin{array}{c}\text { Progress of } \\
\text { completing the } \\
\text { irrigation work } \\
\text { construction } \\
\text { project }\end{array}$ \\
\hline Investor & 0.82 & & & & & & \\
\hline Peripheral & 0.191 & 0.818 & & & & & \\
\hline Capital & 0.01 & 0.038 & 0.799 & & & & \\
\hline Contractors & 0.289 & 0.236 & 0.282 & 0.833 & & & \\
\hline Consultant & 0.02 & 0.039 & 0.049 & 0.393 & 0.793 & & \\
\hline Convenience & 0.267 & 0.197 & 0.022 & 0.438 & 0.037 & 0.833 & \\
\hline $\begin{array}{l}\text { Progress of completing the irriga- } \\
\text { tion work construction project }\end{array}$ & 0.014 & 0.022 & 0.036 & 0.285 & 0.04 & 0.012 & 0.816 \\
\hline
\end{tabular}

All values outside the diagonal are smaller than the values on the diagonal, which means that the research variables in the research model ensure that the differential validity is satisfied to test the research hypotheses. of the research model. The results of the bootstrap test of research hypotheses are as follows:

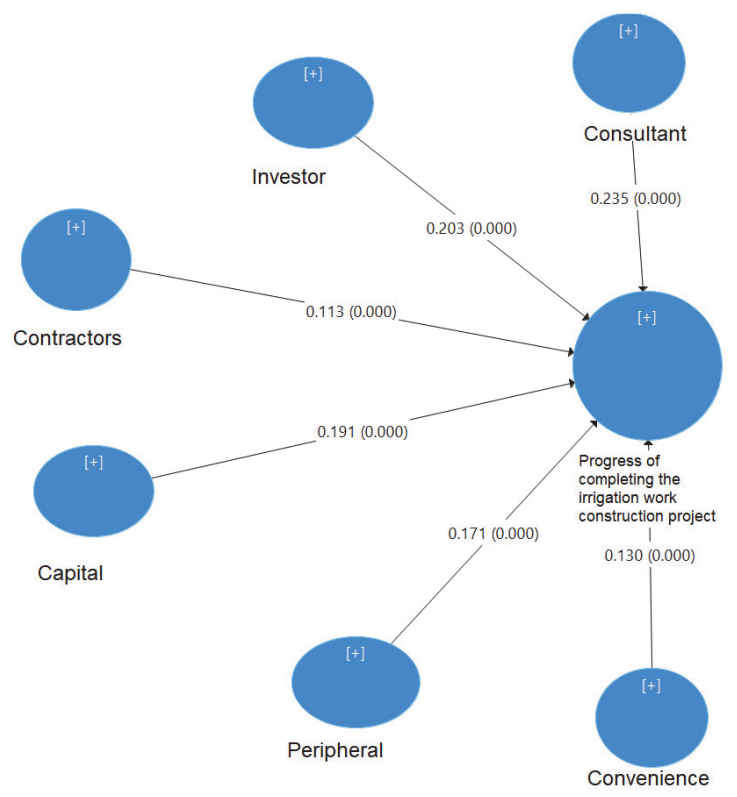

Fig. 2. The results of testing research hypotheses

From the results extracted from the research software, the results show that all 6 factors positively impact the progress of completing irrigation project construction in Thai Binh province. Specifically, the consultant factor has the strongest impact on the completion of an irrigation project in Thai Binh province with the impact factor of 0.235 at the significance level of $1 \%\left(\mathrm{P}_{-}\right.$value $\left.=0.000\right)$. The weakest impact factor is the contractor factor with an impact factor of 0.113 at a significance level of $1 \%\left(\mathrm{P}_{\text {_value }}=0.000\right)$. The results of the research hypotheses are summarized in the following table: 
Table 3

Summary of research hypotheses

\begin{tabular}{|c|c|c|c|c|c|}
\hline & $\begin{array}{l}\text { Original Sam- } \\
\text { ple (O) }\end{array}$ & $\begin{array}{l}\text { Sample Mean } \\
\text { (M) }\end{array}$ & $\begin{array}{c}\text { Standard Deviation } \\
\text { (STDEV) }\end{array}$ & $\begin{array}{l}\text { T Statistics } \\
(|\mathrm{O} / \mathrm{STDEV}|)\end{array}$ & $\begin{array}{c}\text { P Val- } \\
\text { ues }\end{array}$ \\
\hline $\begin{array}{l}\text { Investor } \rightarrow \text { Progress of completing the irrigation work } \\
\text { construction project }\end{array}$ & 0.203 & 0.205 & 0.013 & 15.379 & 0.000 \\
\hline $\begin{array}{l}\text { Peripheral } \rightarrow \text { Progress of completing the irrigation } \\
\text { work construction project }\end{array}$ & 0.171 & 0.169 & 0.011 & 14.908 & 0.000 \\
\hline $\begin{array}{l}\text { Capital } \rightarrow \text { Progress of completing the irrigation work } \\
\text { construction project }\end{array}$ & 0.191 & 0.190 & 0.013 & 14.556 & 0.000 \\
\hline $\begin{array}{l}\text { Contractors } \rightarrow \text { Progress of completing the irrigation } \\
\text { work construction project }\end{array}$ & 0.113 & 0.114 & 0.009 & 13.253 & 0.000 \\
\hline $\begin{array}{l}\text { Consultant } \rightarrow \text { Progress of completing the irrigation } \\
\text { work construction project }\end{array}$ & 0.235 & 0.234 & 0.014 & 17.256 & 0.000 \\
\hline $\begin{array}{l}\text { Convenience } \rightarrow \text { Progress of completing the irrigation } \\
\text { work construction project }\end{array}$ & 0.130 & 0.130 & 0.012 & 10.647 & 0.000 \\
\hline
\end{tabular}

All the hypotheses of the research model are supported.

Adjusted $\mathrm{R}^{2}$ to reflect the influence of the independent variables on the dependent variable. Specifically, in this case, 06 independent variables affected $59.09 \%$ of the changes on the dependent variable. The results of regression analysis show that, at present, there are 06 factors affecting the progress of completing the irrigation project construction using State budget capital in Thai Binh province. This result is also consistent with previous studies. The research model shows that these four factors explain $46.1 \%$ of the variation in the progress of completing an irrigation project using State budget funds in Thai Binh province and accept it. hypotheses about the influence of the inter-factor group.

\section{Conclusion}

In most general construction works, especially irrigation and hydropower projects, the on-time completion of the project on schedule depends on investment efficiency of the contractor as well as the investor. Conversely, if the construction progress is delayed, it will cause some damage to the contractor, but will greatly damage the investor, making the investment ineffective. Therefore, the management and control of construction progress to ensure that the works are executed on schedule is a real issue that needs to be addressed. From the research results, the article proposes several solutions to improve the completion progress of construction projects using the State budget in general and irrigation construction projects using the State budget. as follows:

1. Strengthen the management of construction progress, consider progress as an ordinance to be accomplished as follow,

- Check and urge the construction progress of unit works which must be consistent with the total construction progress,

- Ensure the exact control times on the total progress such as time of blocking flow, completion time of diversion works, completion of construction over floods,

- To do well the work acceptance test, work acceptance of the unit's works, issue price slips and timely allocate capital to encourage and create conditions for the units to complete the work items on time.

2. Based on the total work construction schedule, it is necessary to detail and concretize the construction plan, which is the weekly, monthly, quarterly, or yearly work progress plans to serve as a basis for inspection and monitoring. and as the basis for planning the reasonable technical material supply plan.

3. The work items participating in the diversion plan such as: Drainage to take water through the dam body, hydroelectric tunnel, flood spillway are the key works that need to be paid attention and constructed in a timely and ensured manner.

4. The items as the basis for the installation of equipment to serve the crazy first unit need to have a prioritized plan and synchronous construction to achieve the set goals.

5. Measures are required to control progress to ensure smooth construction progress and achieve reasonable capital expenditure during construction.

Strictly implementing the planned schedule is the goal to reduce costs in the construction process of the construction units. Depending on the conditions of each locality, unit and construction site, new solutions with high efficiency will be offered. The slow disbursement of capital will seriously affect the project implementation progress, so the project management board should request the investor to have timely and appropriate capital mobilization measures, plans, and contingency plans. when facing capital difficulties, to ensure disbursement in accordance with the project schedule, avoid capital shortage, slow payment to construction contractors so that the contractor can ensure sufficient resources to carry out the next works. The Project Management Board should propose investors to implement measures to ensure capital mobilization for the project as follows: 
- Calling and cooperating in investment with secondary investors, especially foreign investors investing heavily in Vietnam with strong financial potentials such as Korea, Japan, The United States, etc.,

- Having a really feasible incentive policy for the employees and their family members when buying a house for the project,

- Develop strategies, promote marketing, PR, approach potential customers and investors to promote effective sales according to the project's progress to have more capital to carry out the project judgment,

- Diversify loan sources for projects,

- Proper construction progress plays an important role in ensuring the construction time of a project so project management must seriously invest time in reviewing, checking and approving exam schedules. construction by the contractor.

Reasonable construction progress is to meet technical requirements with a reasonable construction order, ensure the construction period, use air-conditioning human resources in construction, and stream capital into the works reasonably. To do the above work, it is necessary to apply the process of construction management and approval of construction progress. During the construction process, due to many different reasons, the delay of some work is inevitable, the project management board needs to monitor and take measures to overcome the slow progress, to fulfill the responsibility. In this task, the project management board should adopt a process of monitoring and remedying the construction progress. The results of the study on factors affecting the progress of completing the irrigation works construction project using State budget funds in Thai Binh province show that the research objectives have been achieved. However, like many other studies, this study still has the following limitations:

Firstly, the research is only tested for projects on construction of irrigation works funded by the State budget; Research samples were selected by convenient sampling method, so the generalization of research results is not high.

Secondly, the study uses multiple linear regression analysis to test theoretical models and research hypotheses. Therefore, the interaction between factors affecting the completion of an irrigation work construction project using State budget funds has not been tested.

Because of the above limitations, the repeated studies need to be verified for both BOT projects, ODA-funded projects; projects using FDI capital, etc. for many different time periods of the year, and using other data processing techniques and other analytical methods for a more comprehensive assessment.

\section{References}

Chan, A. P., Scott, D., \& Chan, A. P. (2004). Factors affecting the success of a construction project. Journal of Construction Engineering and Management, 130(1), 153-155.

Dang N. C. (2011). The success factors of the project are implemented according to the design - construction method in the southern region. City University of Technology. HCM City.

Hair, J.F., Ringle, C.M., \& Sarstedt, M. (2011). PLS-SEM: in deed a silver bullet, Journal of Marketing Theory and Practice, 19(2), 139-151.

Hair, J.F., Hult, G.T.M., Ringle, C., \& Sarstedt, M. (2013). A Primer on Partial Least Squares Structural Equation Modeling (PLS-SEM), Sage Publications Ltd, London.

Hair, J.F., Henseler, J., Dijkstra, T., Sarstedt, M., Ringle, C., Diamantopoulos, A., Straub, D., Ketchen, D., GTM, H., \& Calantone, R. (2014). Common beliefs and reality about partial least squares: comments on Rönkkö and Evermann, Organizational Research Methods, 17(2), 182-209.

Hair, J. F., Hult, G. T. M., Ringle, C. M., and Sarstedt, M. (2017). A Primer on Partial Least Squares Structural Equation Modeling (PLS-SEM), 2nd Ed., Sage: Thousand Oaks.

Henseler, J., Ringle, C.M. and Sarstedt, M. (2015). A new criterion for assessing discriminant validity in variance-based structural equation modeling. Journal of the Academy of Marketing Science, 43(1), 115-135.

Nguyen, L. D., \& Ogunlana, S. O. (2004). A study on project success factors in large construction projects in Vietnam. Engineering, Construction and Architectural Management, 11(6), 404-413.

Hoang, T. S. (2008) Set up a model to evaluate the success of a construction project according to PSI indicators. City University of Technology. HCM City.

Ong, S. P., Jain, A., Hautier, G., Kocher, M., Cholia, S., Gunter, D., ... \& Ceder, G. (2011). The materials project. Materials Project.

Tabish, S.Z.S, Kumar A.B.G, \& Neeraj J.H.A. (2011) Identification and evalueation of success factors for public construction projects. Construction Management and Economics (August 2011) 29, 809-823.

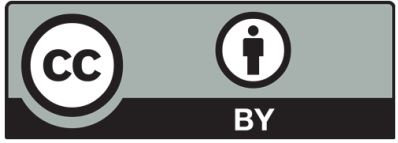

(C) 2021 by the authors; licensee Growing Science, Canada. This is an open access article distributed under the terms and conditions of the Creative Commons Attribution (CC-BY) license (http://creativecommons.org/licenses/by/4.0/). 